\title{
道路盛土の耐震性評価のための地震動設定手法 に関するアンケート調査
}

\author{
一井 康二 1 ・秦 吉弥 $2 \cdot$ 村田 晶 $^{3}$ \\ 1正会員 広島大学大学大学院工学研究院准教授 （干739-8527 広島県東広島市鏡山1-4-1） \\ E-mail: ichiikoji@hiroshima-u.ac.jp \\ 2正会員 日本工営株式会社中央研究所主任研究員（テ300-1259 茨城県つくば市稲荷原2304） \\ E-mail: hata-ys@n-koei.jp \\ 3正会員 金沢大学大学院自然科学研究科助教 （T920-1192 石川県金沢市角間町） \\ E-mail: murata@t.kanazawa-u.ac.jp
}

\begin{abstract}
道路盛土の耐震性評価のためには, 盛土のある各地点における地震動を適切に設定する必要がある。今 日までに様々な地震動設定手法が提案されていることを踏まえると, 盛土の耐震性評価に適した地震動の 設定手法を議論しておくことは有用である。そこで本稿では, 委員会活動の一環として, 地震工学の研究 者・技術者を対象にアンケート調査を実施した結果について報告する. アンケートの内容は, 種々の地震 動設定手法の長所・短所についての技術者の認識の実態と, 著者らが提案している常時微動計測結果によ り線状構造物である道路盛土をゾーニングする方法を実務に適用寸る際の課題である.
\end{abstract}

Key Words : earthquake, embankment, questionnaire, input seismic motion, microtremor measurement

\section{1.はじめに}

道路の耐震検討においては，橋梁等のほかにも， 盛土の地震時崩壊の発生の有無, 崩壊の範囲や程度 を全線にわたり把握することが重要である。そのた めには，各盛土地点における耐震性評価のための地 震動を合理的に設定することが望ましい.

今日，様々な地震動設定手法が提案されているが, それぞれの手法毎に長所・短所が異なると考えられ, 道路盛土の耐震性評価に適した地震動の設定手法に ついての検討を行うことは有意義である。また，手 法の難易度によっては, 技術者の判断や力量などに より設定される地震動の精度等が異なってくる事態 が発生する可能性も，実務的には考えられる.

(社)土木学会地震工学委員会では,「性能を考慮 した道路盛土の耐震設計・耐震補強に関する研究小 委員会(委員長：常田賢一大阪大学大学院工学研究 科 教授)」を平成20年度より設置し，道路盛土の地 震時応答特性・設計地震動, 変形量予測, 而震補強 工法などについて検討を行っている，本稿では，委 員会活動の一環として, 地震工学の研究者・技術者 を対象にアンケート調査を実施した結果について報 告する。アンケートの内容は，種々の地震動設定手 法の長所・短所についての技術者の認識の実態と, 著者らが提案している常時微動計測結果により線状 構造物である道路盛土をゾーニングする方法を実務 に適用する際の課題である。

\section{2. アンケート回答者の概要}

本アンケートは，(社)土木学会および(社)地盤工 学会の名簿などから日本国内における地震工学を専 門とする技術者・研究者を 200 人抽出し, 回答候補 者として選定した. 事務局からアンケート書類を回 答候補者宛てに郵送(2008年9月初旬)し, 候補者が 紙面上でアンケートに回答を記入し, 回答結果を事 務局に返送する方式で実施した。有効回答期間は約 1か月間とした。その結果，有効回答数は83通(有効 回答率41.5\%)であった。

図-1に回答者の属性を示す。回答者自身に対する 調査内容は, 所属機関(同図(a)), 実務経験年数(同 図(b)), 役職(同図(c)), 所有資格(同図(d)), 業務内 容(同図(e)), などの計7項目である.

この図によれば，所属機関としては大学・研究機 関が過半数, 建設コンサルタントが約3割, ゼネコ ンが約1割を占めている。その他の機関としては, 日本高速道路(株)(NEXCO)などで占められている. 実務経験を5年単位で分割すると偏りなく分布して いることが読み取れる。なお，本アンケートでは， 大学・研究機関での在籍年数についても実務経験と して計算している。また，実務経験年数の分布と対 応するように，就いている役職も幅広い。所有資格 としては，技術士(建設部門もしくは応用理学部門), 博士(工学, 理学, 農学, 学術), 1級土木施工管理 技士，1級建築士の4つの資格に着目した結果，どれ 
か一つ以上の資格所有率は，83人中 72 人(約 $87 \%)$ と なっており，技術レベルの高い方に本アンケートを 回答いただいたと判断できる。ただし，年代にばら つきがあること, 資格の位置づけもそれぞれ異なる ことを考えると，技術レベルは高くとも，明瞭な技 術者像を提示できるような集団にアンケートできて いるわけではない点には注意が必要がある.

業務内容(複数回答可)については，約7割の回答 者が研究の項目を挙げている. 回収率等を勘案して 回答候補者を選定した際，偏りがあった可能性もあ ると思われる。具体的な研究内容については，記載 有無に差異があったため, 一概に定量的な評価はで
きないが, 約半数にあたる 57 人 28 人が地震動に関 する内容を挙げている。 また, 本稿の内容に直結し ていると思われる地震動設定の項目を挙げた回答者 は，83人中 $30 人($ 約36\%)となり，4割程度であった。

図-1(f)は，図-1(e)において地震動設定を業務内容 として挙げた回答者の所属機関を整理したものであ る.この図より大学・研究機関とコンサルタント・ ゼネコンでそれぞれ約半数ずつを占めている。なお， 後述するアンケート項目に関連して, 常時微動計測 の経験の有無等の項目も質問したが，これらの質問 の回答は該当する検討内容のところで述べる.

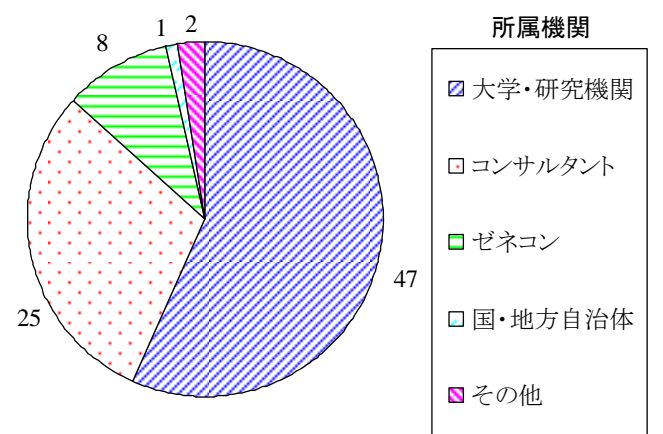

(a) 所属機関

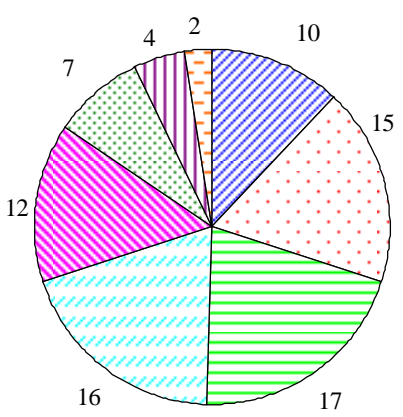

(b) 実務経験

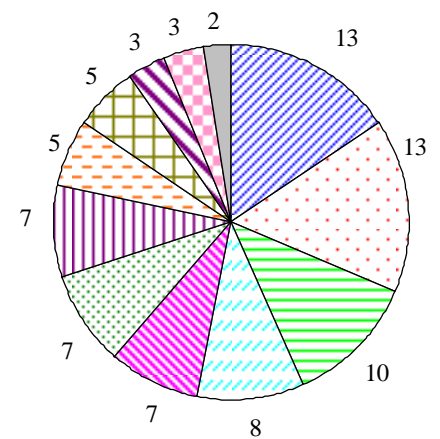

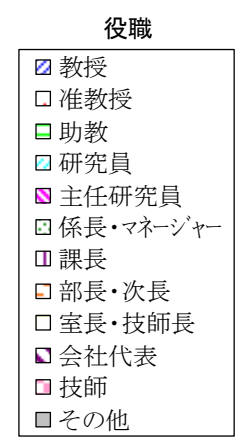

(c) 役職
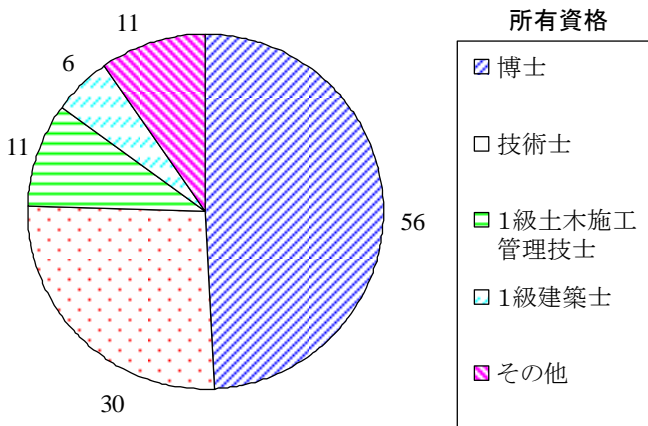

(d) 所有資格（複数回答可）

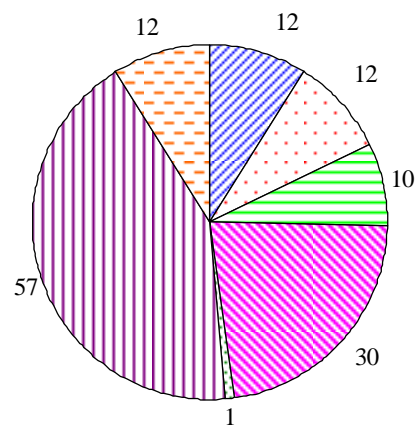

業務内容

曰盛土設計 口現場計測 日港湾空港設計 口施工管理 因地震動設定 曰業務発注 口研究

(e) 業務内容（複数回答可）

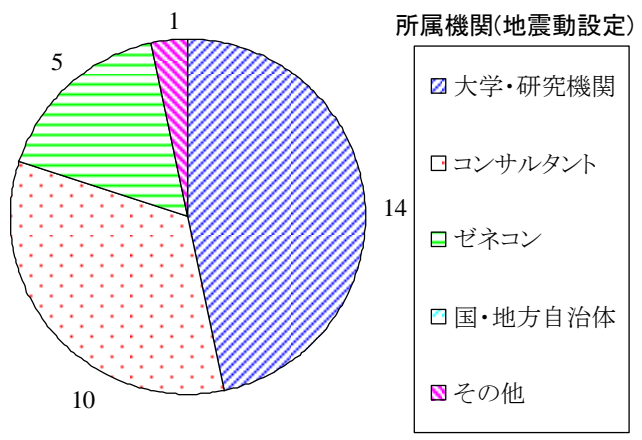

（f）地震動設定を業務内容とする回答者の所属

図-1 アンケートの回答者の属性 


\section{3. 地震動設定手法の特徵についての調査}

\section{(1) 質問内容}

まず，最初に，種々の地震動設定手法の特徵に関 して，技術者の認識を調查した。アンケートの設問 内容は以下に示寸とおりである。ここに，以下の文 面や表は，表番号などを除いて，回答者に送付した ものと同じである。

『質問 II : 盛土の耐震性評価を実施するための検討 地震動を設定することになりました．以下に示寸代 表的な設定手法が提案されていますが，それぞれの 長所・短所に該当すると思われる言葉を下記のキー ワードから選んでご記入いただき，あなたの推奨手 法についてもご記入（複数回答可）ください，（図2 および表-1参照)』

- 手法 1 : 既往の地震による代表的な観測地震波 をそのまま採用

- 手法 2: 距離減衰式などの経験的手法を用い地 震動の振幅レベルを調整した地震波を採用

・手法 3 : 各種スペクトルにフィッティングさせ たスペクトル適合波を設定・採用

- 手法 4: 統計的グリーン関数法などの半経験的 手法を用いて地震動を計算・作成

・手法 5 : ハイブリッド法などの理論的手法を用 いて地震動を計算・作成

\section{(2) 回答結果}

選んで頂いた地震動設定手法のキーワード（図-2 参照) に対し，図-3 に示すように項目ごとに一般的 な優劣を考慮したポイントを付与して，5段階評価 を行った。ここに，費用および作業性については， キーワード記載順 (図-2 参照) とポイント付与順を 反転させていることに留意されたい。また，入力デ ータ (パラメータ)の数については, 一概に優劣を考 慮できないため, キーワード記載順 (図-2 参照)の 通りにポイントを付与した。

図-4に，各キーワードに対する平均值ならびに 標準偏差を示す．同図は, 長所として回答した方の 5 段階評価ポイント (左図), 短所として回答した方 の 5 段階評価ポイント (中央図), 有効回答数 (右図) を各地震動設定手法に対してそれぞれ比較したもの である。ただし，同じ特徴を長所としても短所とし てもみな寸ことができる場合があり，その点を考慮 すると設問自体に問題があったともいえ, 結果の解 釈はそのまま行うことは難しい面もある。例えば, 図-4(d)中央図に示す手法 4 の回答結果には標準偏差 が示されていない。これは, 手法 4 の短所として理 論性・科学性を指摘した回答者が少なく, 数少ない 回答者の全員が 3 点となる回答をしたためである. 一方で, 図-4(c)の手法 1 および手法 2 も, 短所とし ての回答者が少ないが，数少ない回答が異なってい たため, 大きな標準偏差となっている.このように, 回答毎の母集団のサイズが異なる結果となったこと
も問題であり，解釈が非常に難しい.

とはいえ, 回答を分析すると, 図-4(a)㧍よび図4(c)に示すように, 費用および作業性に関しては, 手法 1 および手法 2 の評価ポイントが高く, 優れて いると評価されている。，一方，手法 4 および手法 5 の評価ポイントは低く, 劣っていると評価される.

図-4(b)および図-4(d)に示すように，信頼性およ び理論性・科学性に関しては, 手法 3 および手法 4 の評価ポイントが比較的高く, 若干優れていると評 価されている。，一方で，手法 1 および手法 2 の評価 ポイントは比較的低く, 若干劣っていると評価され ている。しかしながら, 評価ポイントにあまり大き な差異はない. 特に, 手法 1, 手法 2, 手法 3 の評 価ポイントはほぼ同様である.

図-4(e)に示すように，入力データ (パラメータ) の数に関しては, 手法 5 の評価ポイントが最も高く, 一方で, 手法 1 の評価ポイントが最も低い。ここで は, 各地震動設定手法に顕著な差異が確認できる.

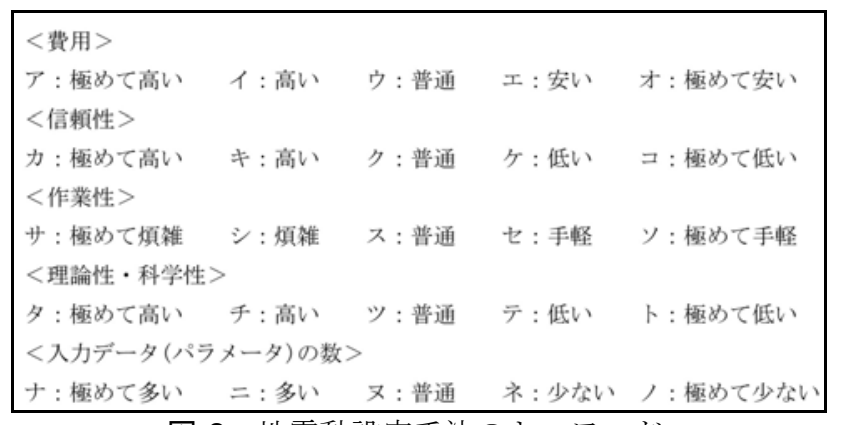

図-2＼cjkstart地震動設定手法のキーワード

表-1 質問 II $の$ 回答例

\begin{tabular}{|c|c|c|}
\hline & 長所 & 短所 \\
\hline 手法 1 & ア, ク, シ, テ, ノ & オ, ク, ス, ニ, 八 \\
\hline 手法 2 & オ, ス, ト & エ, ケ, セ, ヌ, ヘ \\
\hline 手法 3 & ケ, テ, ネ & ア, シ \\
\hline 手法 4 & カ, サ, ナ, 八 & ウ, ク, ス, ツ, ヌ \\
\hline 手法 5 & コ, ソ, ツ & サ \\
\hline 推奨手法 & \multicolumn{2}{|c|}{ 手法 4 と手法 5 } \\
\hline
\end{tabular}

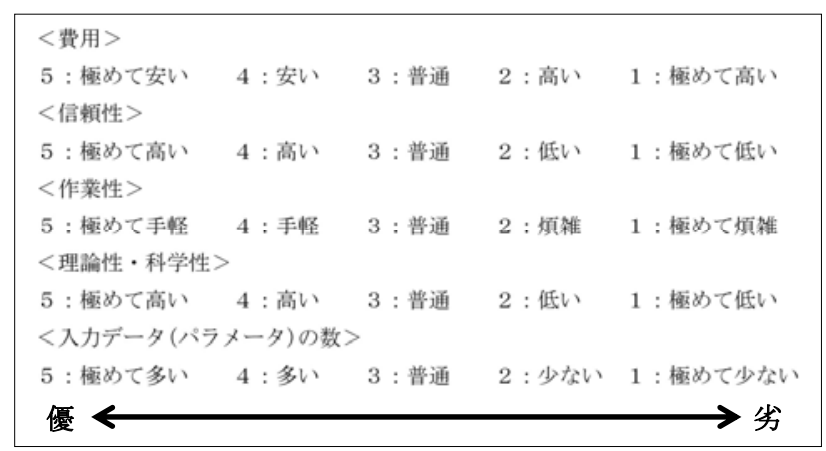

図-3 キーワードの 5 段階評価（ポイントの付与） 


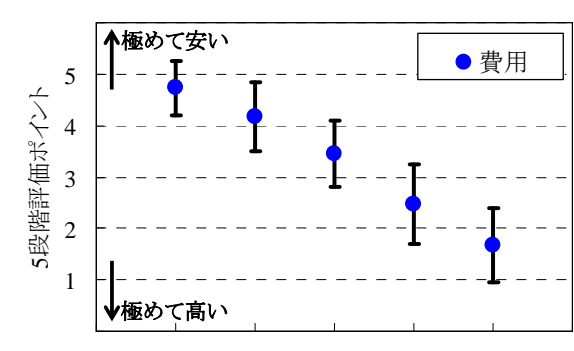

手法1 手法2 手法3 手法4 手法5
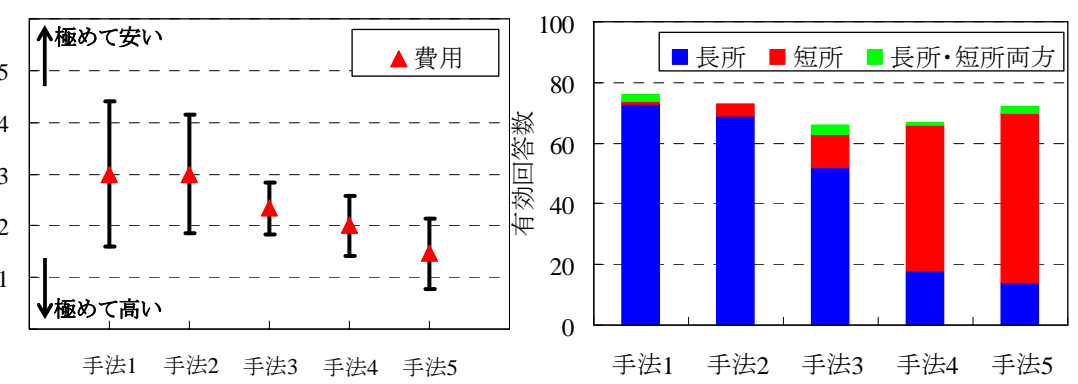

手法1 手法2 手法3 手法4 手法5

(a) 費用（左図 : 長所, 中央図 : 短所, 右図 : 有効回答数)
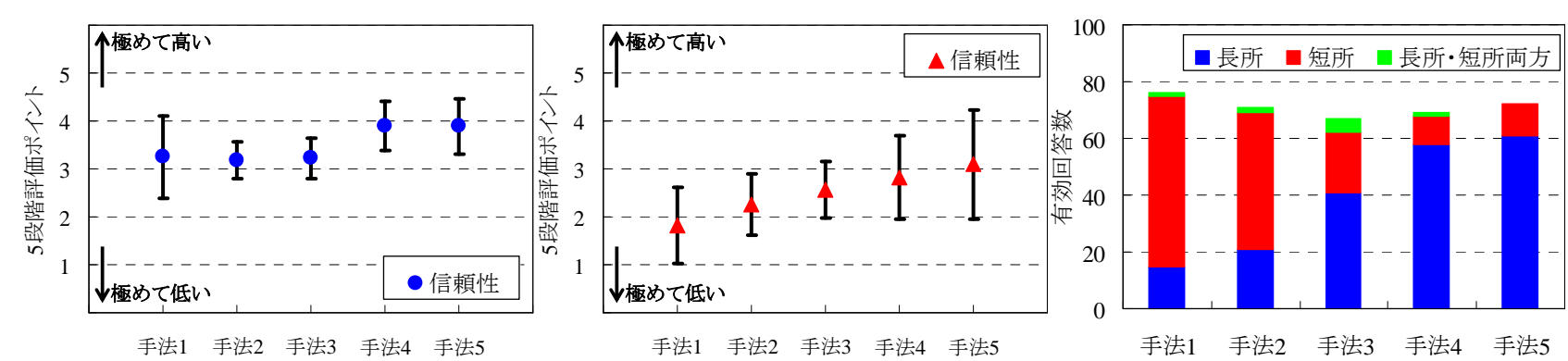

(b) 信頼性（左図 : 長所, 中央図 : 短所, 右図 : 有効回答数)
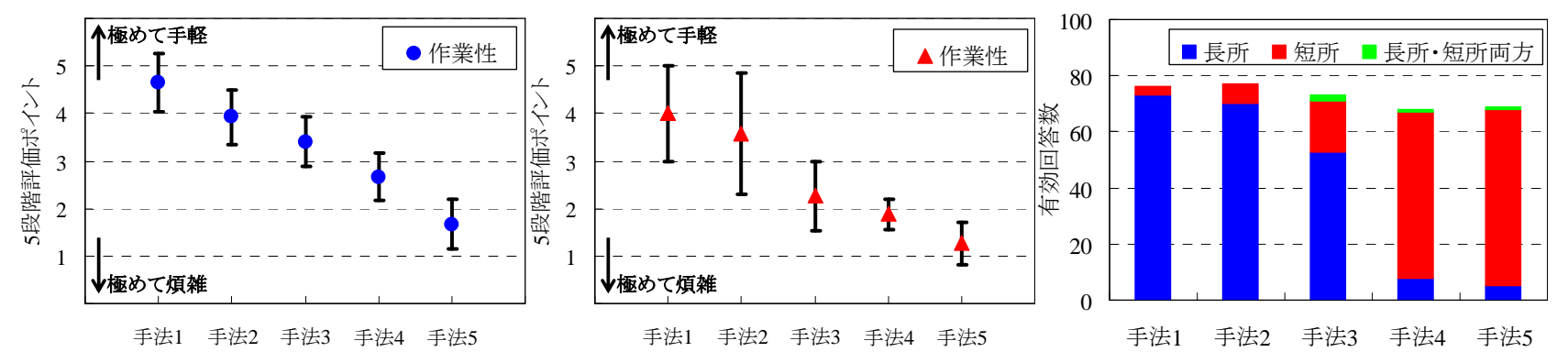

(c) 作業性（左図 : 長所, 中央図 : 短所, 右図 : 有効回答数)

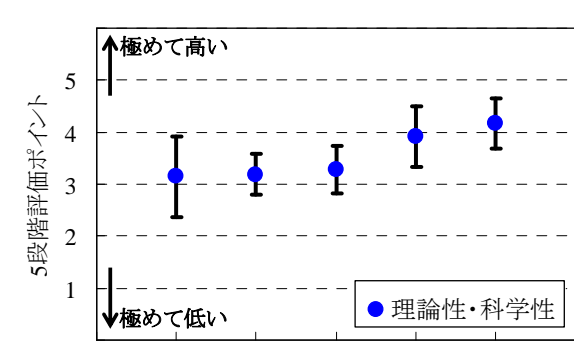

手法1 手法2 手法3 手法4 手法5

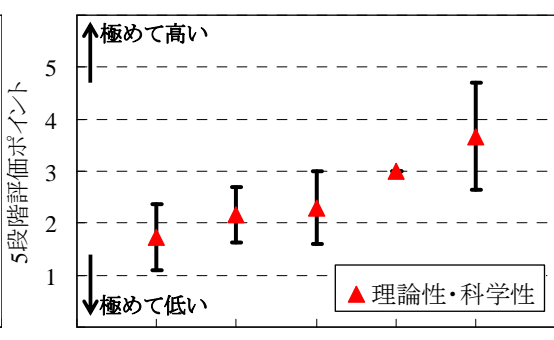

手法1 手法2 手法3 手法4 手法5

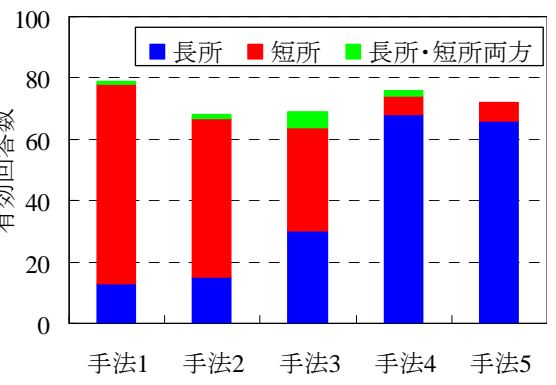

手法1 手法2 手法3 手法4 手法5

(d) 理論性・科学性 (左図 : 長所, 中央図 : 短所, 右図 : 有効回答数)
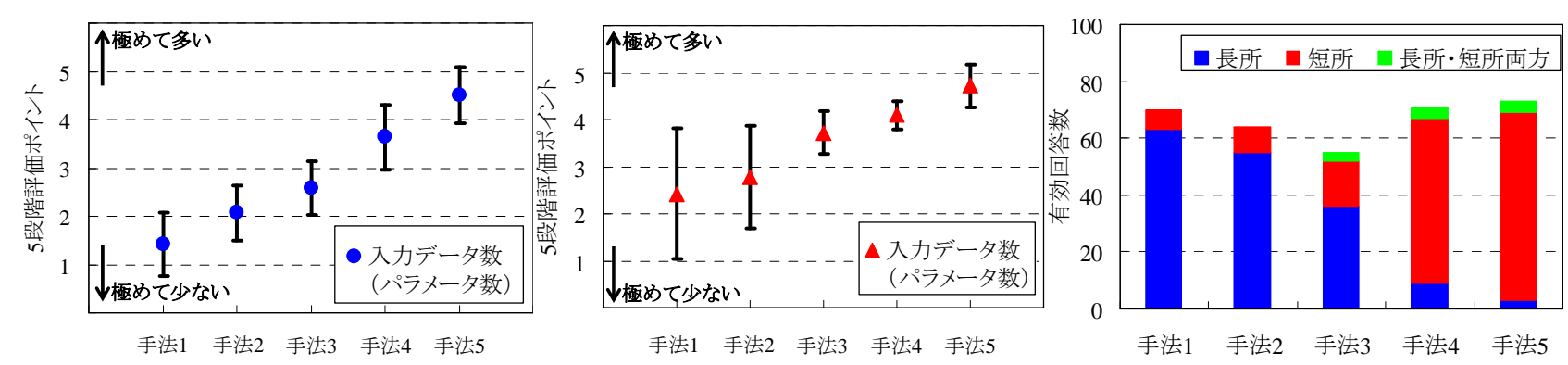

(e) 入力データ (パラメータ) 数 (左図 : 長所, 中央図 : 短所, 右図 : 有効回答数)

図-4 地震動設定手法の特徵（回答者全員） 
そして，手法 1 および手法 2 では，入力データ数 が比較的少ないことが長所として挙げられ, 手法 4 および手法 5 では, 入力データ数が比較的多いこと が短所として挙げられる傾向が強い。また，図一 4(e)の右図からわかるように, 入力データの数の大 小は, 長所としても短所としても解釈できるとする 回答者の割合も比較的多い. 特に, この傾向は, 手 法 3, 手法 4, 手法 5 において顕著に表われている。

なお，図-4で示したものと同様の検討について， 回答者の所属機関や業務内容を考慮した比較も実施 したが，大きな差異は確認できなかった。

\section{4. 常時微動計測についての調査}

\section{(1) 質問内容}

著者らは, 道路の各地点ごとに地盤震動の特性な どが異なってくるをとえば, 1)ことを踏まえ, 常時微動 計測により地盤震動特性を評価し, 線状構造物であ る道路盛土を震動特性の類似した区間にゾーニング する方法の適用事例等を示してきた ${ }^{2), 3)}$.もちろん， この手法については賛否両論あることが考えられる. そこで, 特に否定的な意見が出る可能性のある 2 項 目として, 常時微動の計測条件の影響と, 計測結果 の解釈に関する技術者の判断のばらつきを把握す心゙ く, これらに関連した項目をアンケート調査に含め ることとした．本章では，まず，常時微動の計測条 件に関する調査結果を示す。

アンケートの設問内容は以下に示すとおりである. ここに，以下の文面や図は，図番号などを除いて， 回答者に送付したものと同じである.

『質問 III：図-5 のような形状を有する既存の高速 道路盛土の耐震診断に用いる地震動を検討するため, 常時微動計測を実施することになりました。あなた は，1.どの位置で，2.どのような，常時微動計測を 実施しますか? 実施位置を図示したうえで，その計 測時間などの計測条件などもお書きください(図-6 参照).』

なお，本質問における高速道路盛土の形状や寸法 など (図-5 参照) は, 道路盛土の地盤調査に関する 既往のアンケート調査 ${ }^{4)}$ と同様のものである.

\section{(2) 回答結果}

図-7に 83 人の有効回答者が選定した常時微動計 測条件を示す. 同図(a)は, 常時微動計測の代表的 な回答位置を示したものである.この図より法肩お よび法尻での同時計測が最も多くなっており, 次い で, 法尻のみ, 法尻十中腹十法尻, 天端のみ, 周辺 平坦地盤の順となっている．計測位置の選定に関す るコメントによれば，法尻において常時微動計測を 行い当該地点の基礎地盤の震動特性を把握すると同 時に, 車両通行に伴う振動が少ないのであれば, 法 肩，天端，中腹などにおいても計測を行い盛土自体 の震動特性についても把握しておく必要があるなど
の意見が比較的多く寄せられた。また，法尻のみに おいて常時微動計測を実施すると盛土の震動特性の 影響を受ける可能性があるためたとえば，5)，盛土法尻 から盛土幅程度離れた平坦な水平成層地盤上におい て常時微動計測を実施すべきであるとの意見も比較 的多く寄せられた。

同図(b)は，常時微動計測時間に関する回答を 10 分間隔で取り䌂めたものである。この図より 11〜 20 分間, $1 \sim 10$ 分間の順に多くなっており, 両計測 時間の回答で過半数以上を占めている.これは，一 般の常時微動計測が, この程度の計測時間で実施さ れているということを示しているものと思われる。 一方で, 20 分間を超える回答が $1 / 4$ 以上あり, 60 分を超える計測時間の回答もあったことは, 高速道 路であるため, ノイズ等の影響を懸念した回答であ ることも考えられる，この点については，交通量等 の条件を明示してないため, 設問の不備に起因して ばらつく回答となったとも解釈できる.

同図(c)は, 常時微動計測方向に関寸る回答であ る. この図より断面, 延長, 鉛直方向の計 3 方向で の計測が 6 割以上を占めている. 同図(d)は, 常時 微動計測機器に関する回答である。この図より約半 数が比較的低周波数領域までの計測が可能な速度計 を選定している.この理由は定かではないが，低振 動数領域の計測により, なるべく深いところまでの 情報を取得したいといった理由が考えられる。一方 で, 速度計よりも加速度計の方が一般に安価で取り 扱いが容易なことから, 加速度計を選定した回答者 は，「この程度の計測であれば加速度計でも十分で ある」という判断をしていた可能性もある. 本設問 では，制約条件が明確でないため，一概にどちらが よいとは結論付けることができない.

なお，アンケート回答者のうち，常時微動計測の 経験があるのは 61 人であった。しかし, 常時微動 計測の経験者の回答と回答者全員の回答を比較して も，計測時間に関する回答に若干の違いがあったほ かは，大きな差異は確認できなかった。これは，本 アンケートの回答者の多く(約 73\%) が常時微動計 測に関する経験を有しているためでもあるが，基準 化等がされていないにもかかわらず，常時微動の計 測方法にある程度の一般性が存在しているからであ ると解釈することもできる.

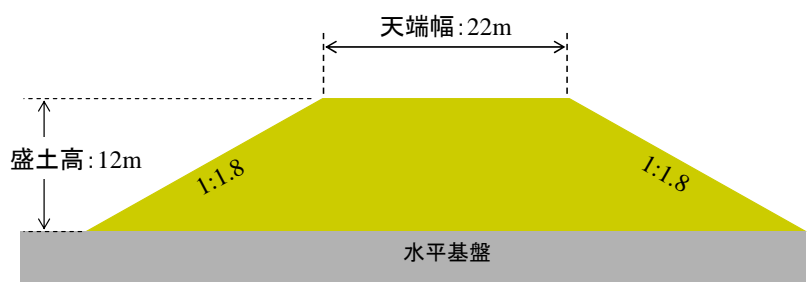

図-5 質問 III において対象とする高速道路盛土 ${ }^{4)}$ 


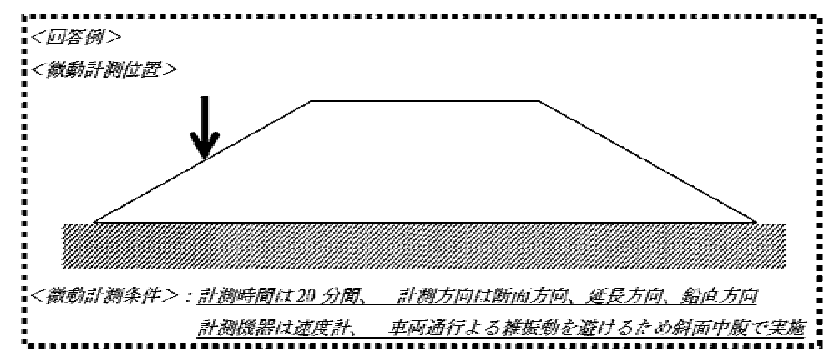

図-6 質問IIIの回答例

\section{H/Vスペクトルに基づくゾーニング についての調査 (その1)}

\section{(1) 質問内容}

実際に常時微動計測を行った場合，計測結果を $\mathrm{H} / \mathrm{V}$ スペクトルで示し, 地盤震動特性を分析するこ とが多い。著者らも，H/Vスペクトルの形状に基づ いて道路の区間を類似した震動特性ごとにゾーニン グを実施してきた。しかし，H/Vスペクトルの形状 によりゾーニングを実施した場合，技術者の判断が 介在するため, ゾーニングの結果に普遍性が見られ るかどうかが不明である。すなわち，技術者の判断 によって，ゾーニングが大きく異なる可能性があり， 実務において常時微動計測結果を用いる場合の障害 となる恐れがある。そこで，ゾーニングの判断が技 術者によりばらつく可能性の有無や程度を明らかに することを目的に設問を設けた。

アンケートの設問内容は以下に示すとおりである。 ここに，以下の文面や図は，図番号などを除いて， 回答者に送付したものと同じである。また，本質問 における高速道路盛土と常時微動計測結果 (図-8お よび図-9)は，高速道路の通行機能の耐震性評価手 法の適用2),6)を行った盛土と同地点である.

なお，回答例には，他と傾向が異なるために判断 できない地点という趣旨で「特異点」の例示を示し ている。しかし，アンケート文面中には，特異点の 定義を明確には示していない。

『質問IV：日本国内のある高速道路のインターチェ ンジ(SJ I.C.〜SW I.C.)間において常時微動計測を実 施した結果 $(\mathrm{H} / \mathrm{V}$ スペクトル：0.05Hzの Parzen Window)を示します。計測場所は盛土の法尻位置で, 計測点数は対象I.C. 間(約 $11 \mathrm{~km})$ の計41地点です. 得 られた地盤震動特性 (H/Vスペクトルの特性)に基づ いて, 対象I.C. 間を複数のエリアに分割 (ゾーニン グ）したいと思います。それぞれ指定する分割エリ ア数に応じた，分割するエリアの端部の位置番号を 明示してください.（図-8，図-9，図-10参照)』

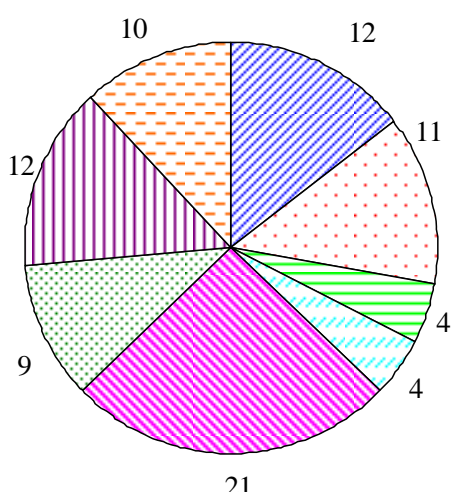

(a) 計測位置

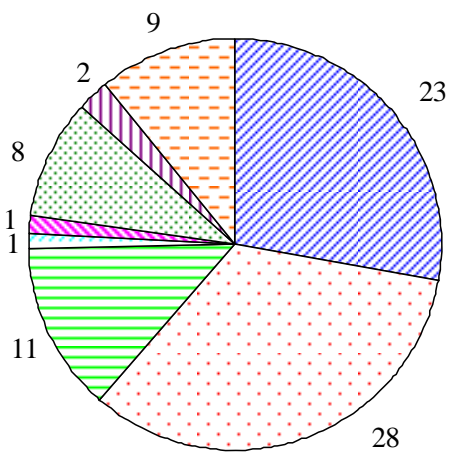

(b) 計測時間

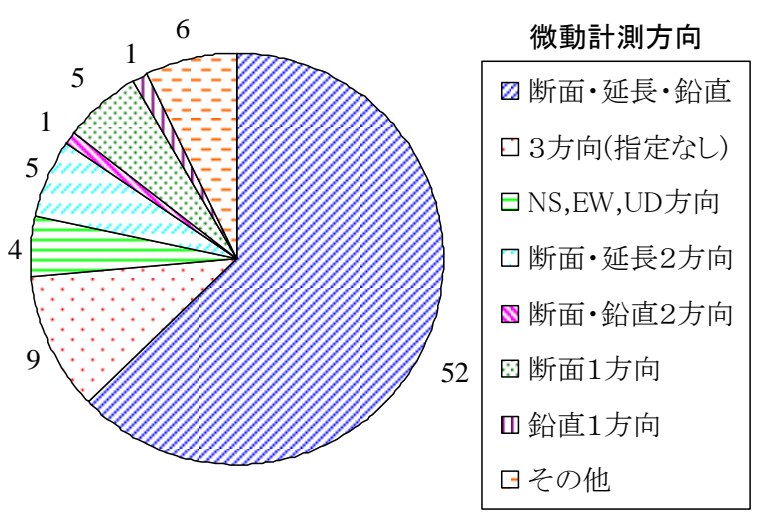

(c) 計測方向

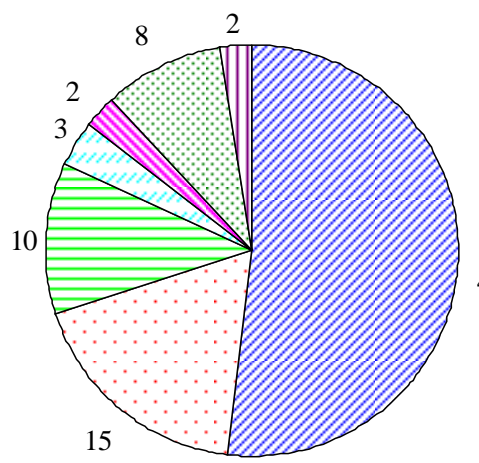

微動計測機器

四速度計

$\square$ 加速度計

曰速度計もしくは 加速度計 口特になし

、高感度地震計

回記載なし

ロその他

(d) 計測機器

図-7 常時微動計測条件 （回答者全員） 


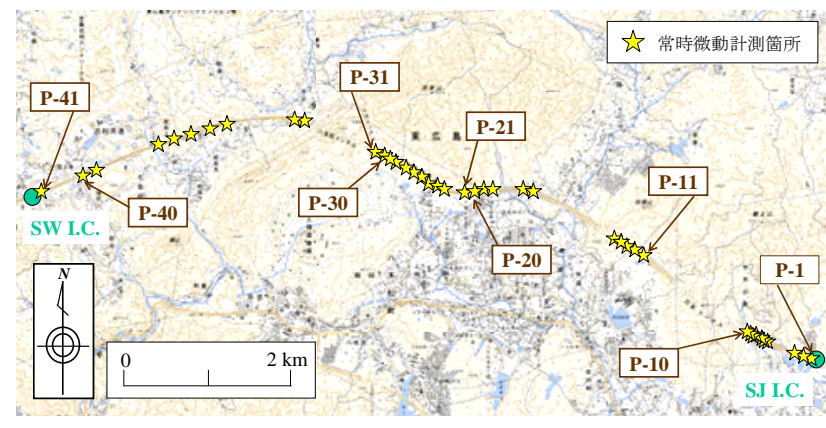

図-8＼cjkstart高速道路盛土法尻における常時微動計測位置

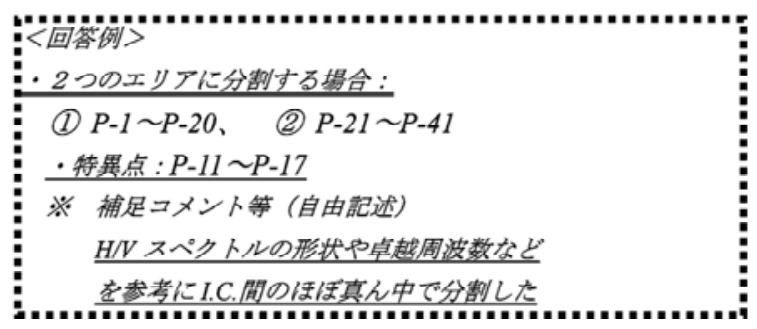

図-9 質問IVの回答例

\section{（2）頂いた意見およびコメント}

回答結果を述べる前に，自由意見として記述いた だいた意見およびコメントをまず概観する。

まず，本質問は，ゾーニングのための情報として 検討対象地点の地形図 (図-8)と H/Vスペクトル (図10）のみを提示しているため，情報が少なく，ゾー ニングの実施は困難であるとの回答が比較的多く寄 せられた。すなわち，実際にゾーニングを実施する 際には，与えられた情報以上に，現地の地質等に関 する情報を収集・整理することも肝要で，問題設定 としては不十分であるという意見である。 また，与 えられた情報から無理に実施する場合には，H/Vス ペクトルのピークの有無で分割する程度のゾーニン グしか実施できないとの意見が多くみられた。

つまり，ゾーニングの観点がはっきりしていない ので，地形やH/Vスペクトルだけの情報で分割する のは困難であり，道路下の地盤構造，盛土の施工時 期, 周辺の地質・断層の分布などもゾーニングに反 映すべきとの意見が多く寄せられた。これらの意見 はもっともであるが，これらを反映した調査項目の 設定は難しく，今後の課題である.

さらに, 必ずしもエリアが連続的になるとは限ら ないため，2つまたは4つのエリアに分割するのは困 難であり，飛び地があっても良いとの意見もあった

そもそも，常時微動の計測結果 (H/Vスペクトル) を信じてゾーニングを行うことや，ゾーニングを行 うこと自体についても賛否両論ある課題である。実 務的には，予算や検討期間，入手可能な情報の質と 量などの個別の事情に応じて用いる手法が選択され ることが一般的であろう。その意味では，かなり強 引な課題設定であったにもかかわらず，意図を組ん で多くの方に回答いただいたことになる，深く，皆 様に感謝の意を表したい.

そして，本報告では，検討対象地点における地形
および常時微動計測結果 (H/Vスペクトル)のみの情 報をもとに道路盛土のゾーニングをあえて実施した 場合として，回答結果を以下の通り分析した。

\section{(3) 回答結果 (指定分割エリア数 : 2)}

図-11に83人の有効回答者が選定したゾーニング パターンの回答結果 (2分割指定の場合)を示す。同 図(a)は分割点，同図(b)は特異点の位置である.

ここに，同図(a)および同図(b)の縦軸の回答率と は，分割点および特異点の回答数を有効回答者数 (83人)で除したものである.図-11(a)に示すように， 約8割の回答者がP-17とP-18の境界での分割を選択 している. 特異点としては，図-11(b)に示すように， P-5, P-34, P-38, P-41を選択する回答が多い.これら の結果を踏まえた最多回答を得たゾーニングパター ンを図-11(c)に示す.ゾーニングの判断材料として は, H/Vスペクトルの形状, ピーク周波数, 地形情 報などを挙げた回答者が非常に多く見られた。一方 で，H/Vスペクトルのパターンが多岐にわたってい るため, 2分割するのは, 不可能との回答も見受け られた。また, 西端にあたるP-41を特異点に挙げた 回答者の意見として, 設問はインターチェンジ (I.C.)間の地盤震動特性などを対象としているが, ゾーニングの対象区間をI.C. 間に特に限定する必要 はないとの意見もあった。

この結果をまとめると，2分割の困難性は指摘さ れているものの, 約 $80 \%$ の回答者が同意する分割点 が設定できている。すなわち，ある程度普遍性のあ るゾーニングが可能だと解釈できる。一方で，特異 点の回答率は，最も大きなものでも約50\%の同意に 留まっており, 分割位置ほどの普遍性は確認できな い. なお, これらの結果は, 回答者のうち, 常時微 動計測ならびにゾーニングの経験がある者38人の回 答においてもほぼ同様であった。

\section{(4) 回答結果 (指定分割エリア数：4)}

図-12に 83 人の有効回答者が選定したゾーニング パターンの回答結果 (4分割指定の場合)を示す。同 図(a)は分割点の位置, 同図(b)は特異点の位置であ る。図-12(a)に示すように，約8割の回答者がP-10 とP-11の境界およびP-17とP-18の境界, 約4割の回 答者がP-31とP-32の境界での分割を選択する結果と なった。また，分割不可の回答は，約1割であり，2 分割指定の場合 (図-11(a)参照) と大きな差異はない. 特異点としては, 図-12(b)に示すように, P-5, P-34, P-38, P-41を選択する回答が多く, この結果は, 2分 割指定の場合 (図-11(b)参照) と同じ結果である. 図 -12(c)には，最多回答を得たゾーニングパターンを 示す.ゾーニングの判断材料としては，2分割指定 の場合に見られたH/Vスペクトルの形状，ピーク周 波数, 地形情報だけでなく, 指定分割数の自由度が 増えたため，施設情報や維持管理などを挙げた回答 者が数多く見られた。具体的には，P-10とP-11の境 界およびP-31とP-32の境界に位置する延長 $1 \mathrm{~km}$ 程度 のトンネルを考慮した回答が目立った。 

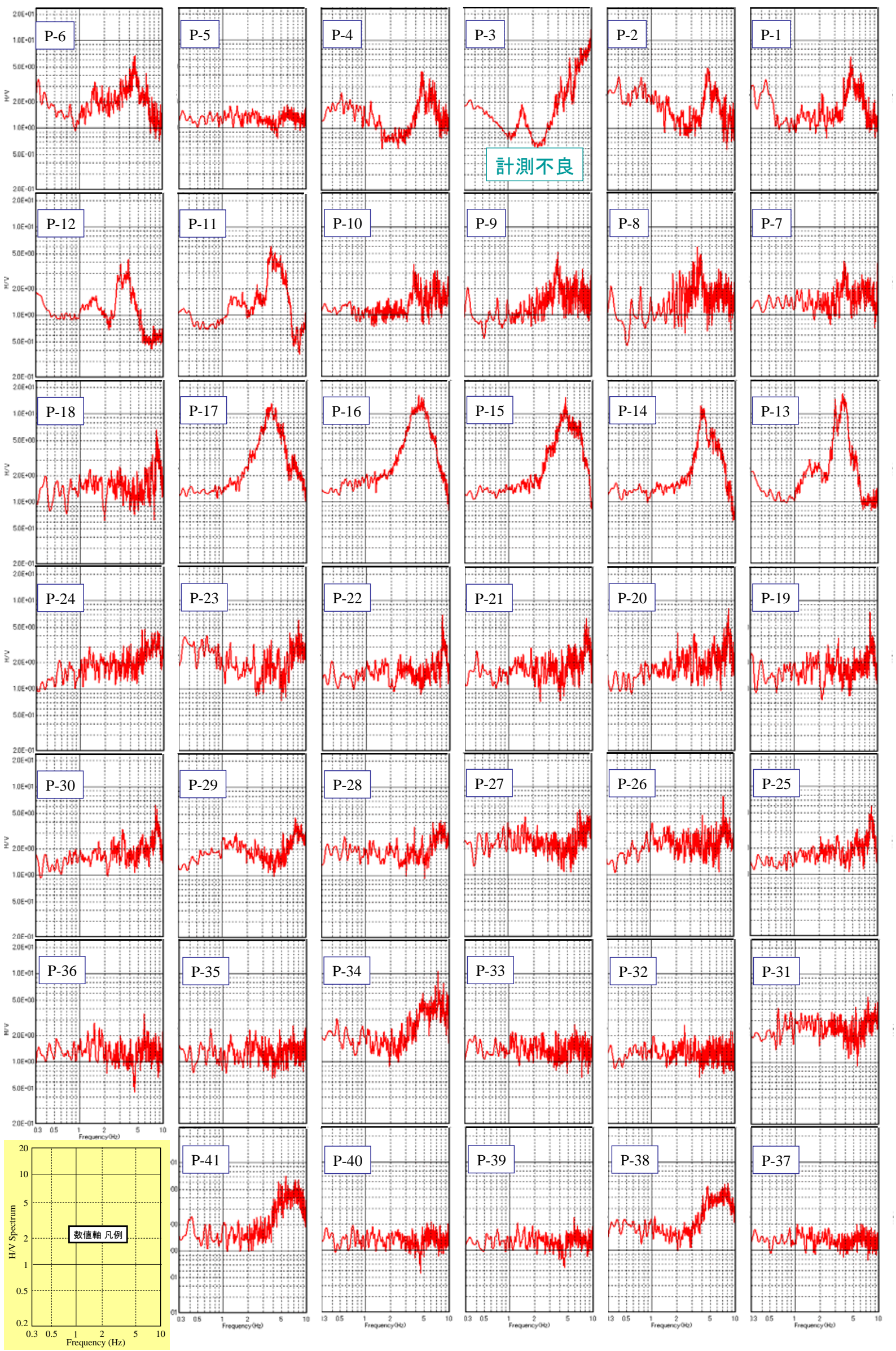

図-10 各計測地点における $\mathrm{H} / \mathrm{V}$ スペクトル 


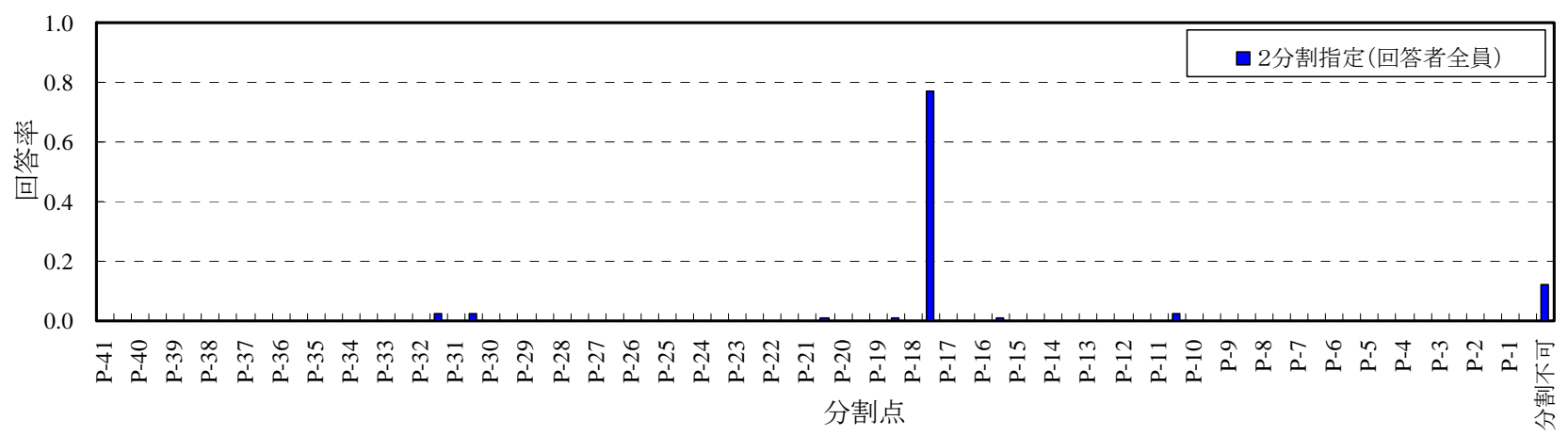

(a) 分割点の位置

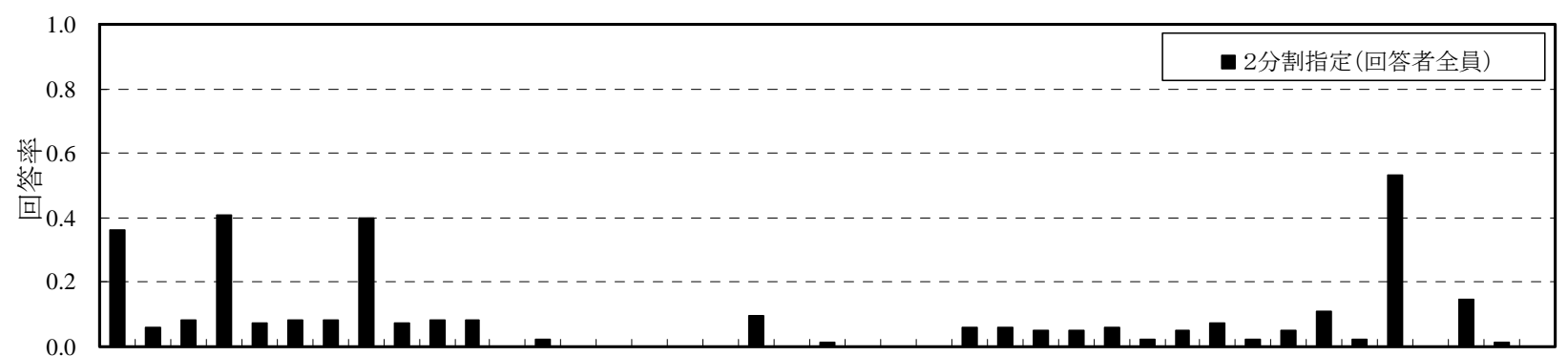

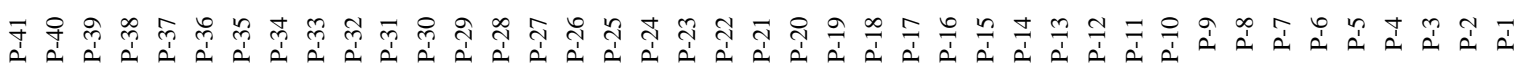
特異点

(b) 特異点の位置

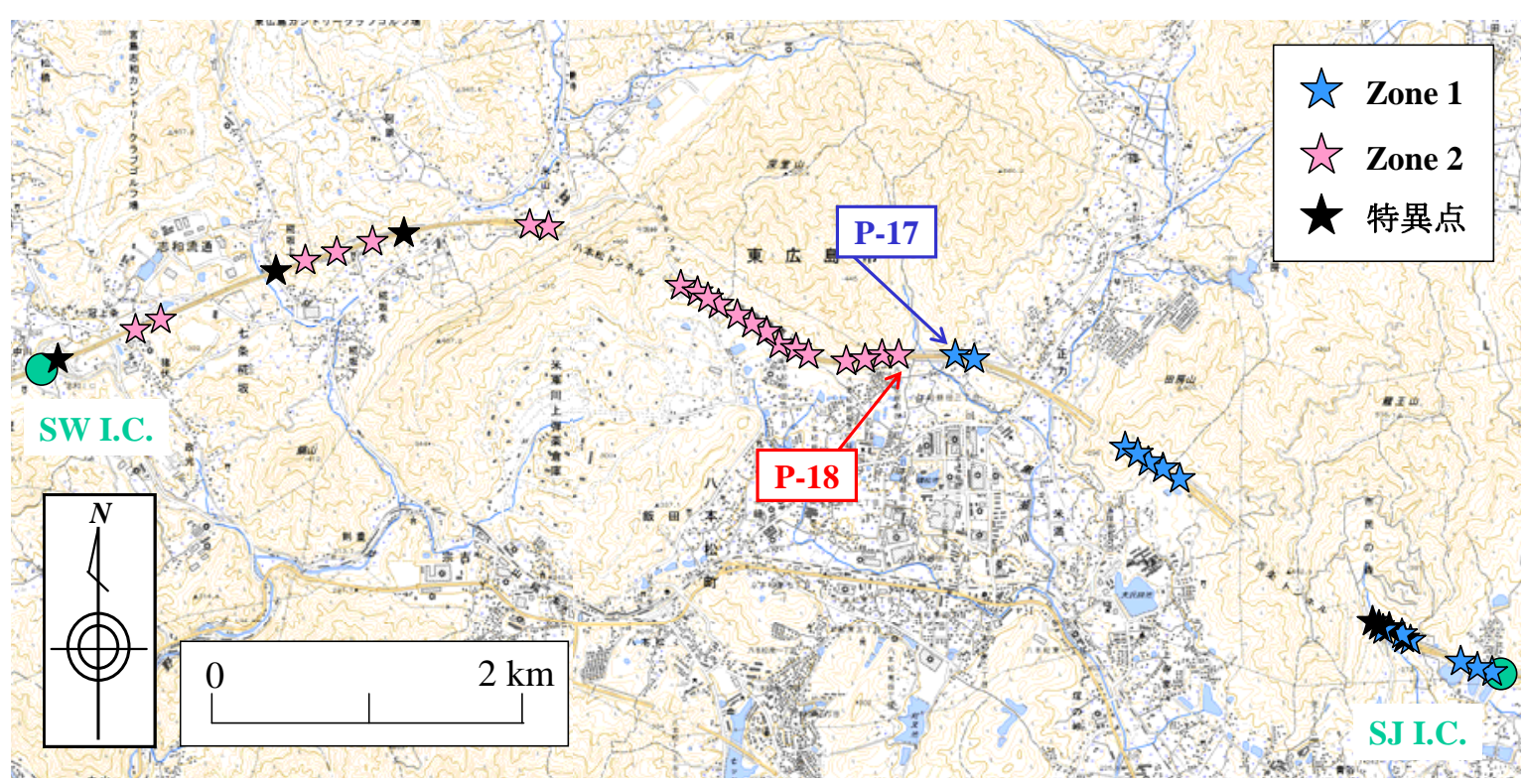

(c) 最多回答のゾーニングパターン

図-11２分割指定の場合のゾーニングパターン（回答者全員）

また，維持管理の容易さを考慮して各々のゾーン 長が概ね同等になるように分割する回答もあった.

この結果をまとめると，4分割であっても40〜 80\%の回答者の同意が得られる分割点が設定できて いる。すなわち，指定分割数の増加により普遍性は 若干低下するが，それでも，ある程度は普遍性のあ るゾーニングが可能であることがわかる。
一方で，特異点の同意率は最大でも50\%程度であ る。また，指定分割数が特異点の選択に及ぼす影響 は比較的小さいこともわかった。

なお，常時微動計測ならびにゾーニングの経験が ある者38人の回答においても，ほぼ同様の結果であ ることを確認した。 


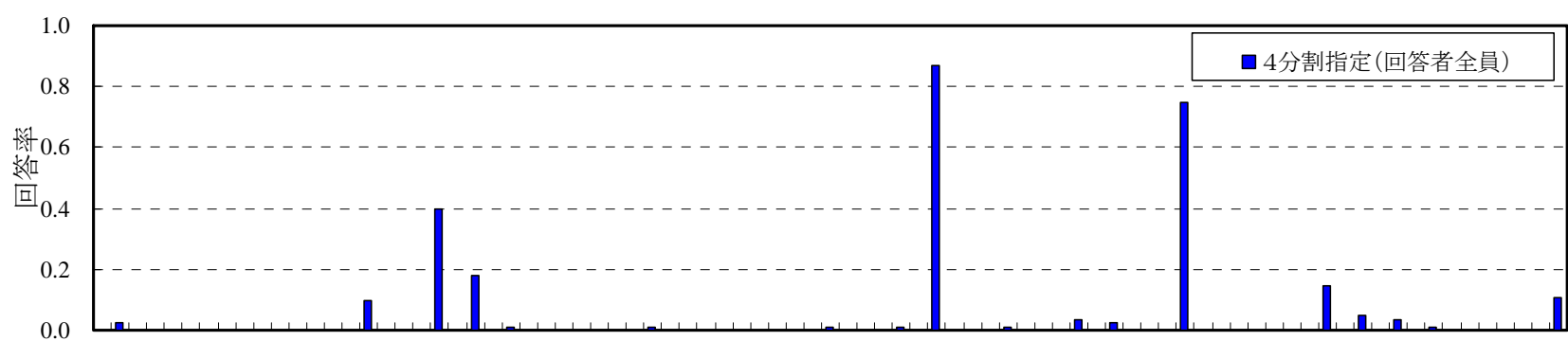

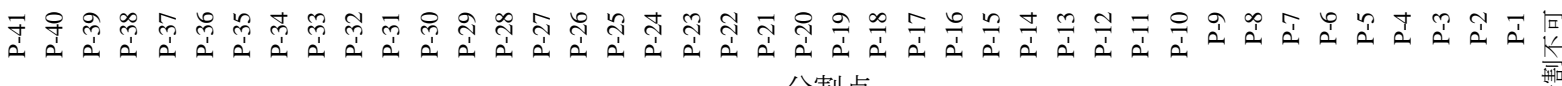
分割点

(a) 分割点の位置

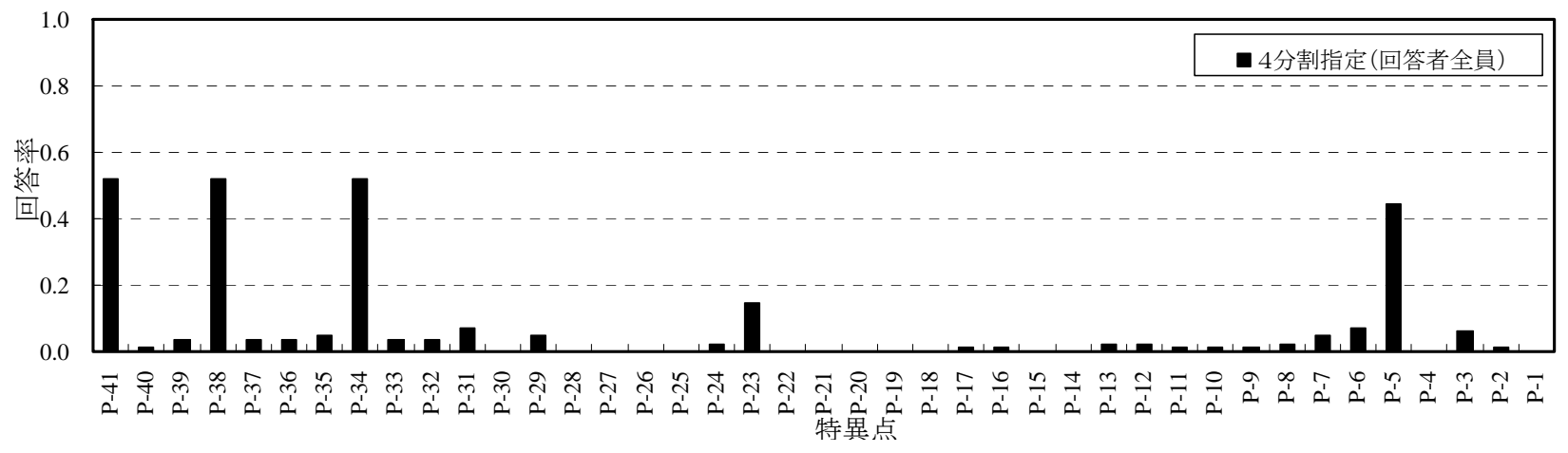

(b) 特異点の位置

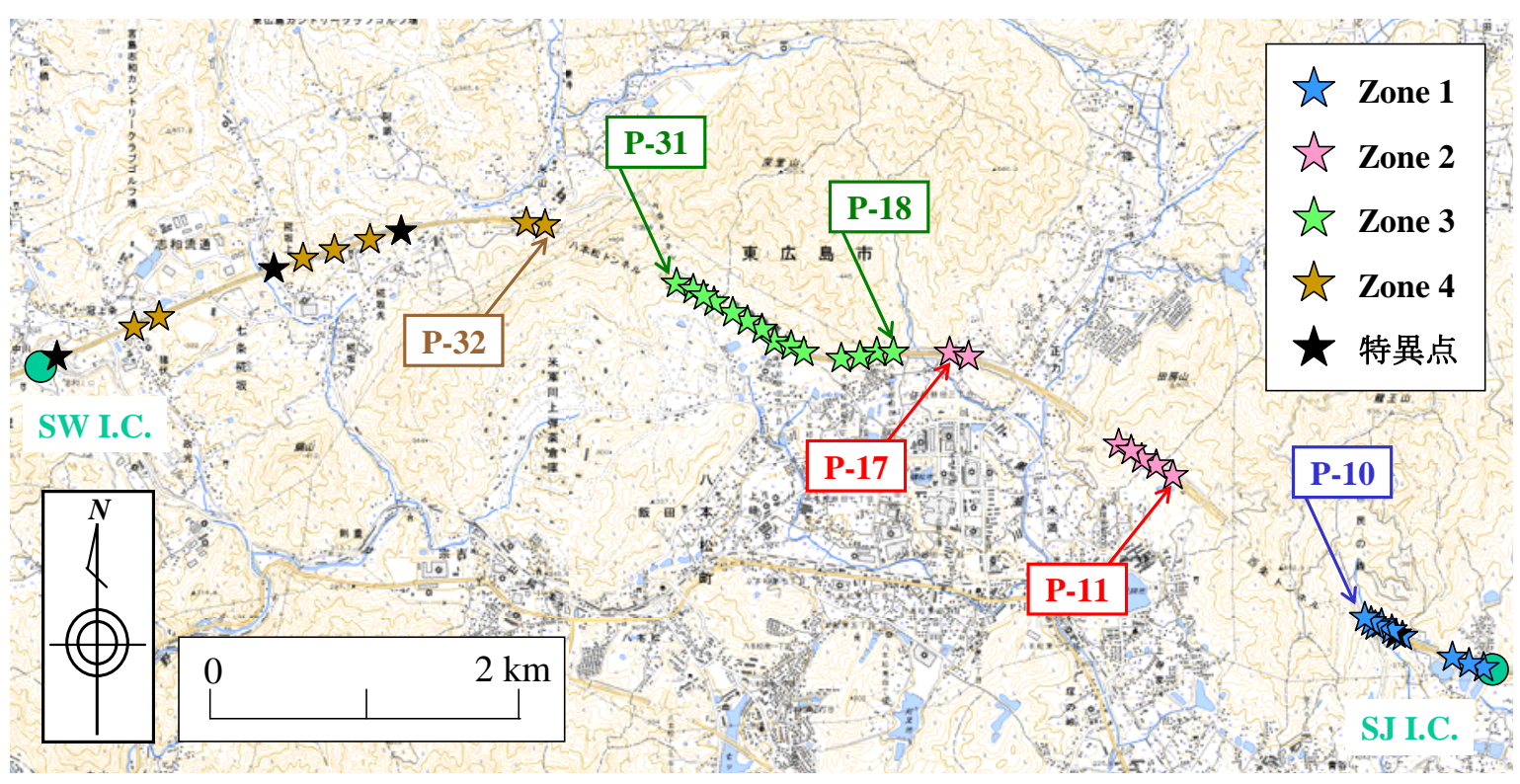

(c) 最多回答のゾーニングパターン

図-12４分割指定の場合のゾーニングパターン（回答者全員）

\section{H/Vスペクトルに基づくゾーニング についての調査 (その2)}

\section{(1) 質問内容}

前章の高速道路盛土のゾーニングに関する設問で は，日本国内における匿名の地点の盛土を対象とし
ていた。しかしながら，実際の実務などでは，H/V スペクトルの特性のほかに検討対象地点周辺の地 形・地質情報，強震観測点の分布，大地震による被 災実績などもゾーニングの判断材料になると考えら れる.すなわち，与条件の種類や数によって分割数 や分割位置などのゾーニングの傾向が変わってくる ことも予想される。 
そこで本検討では， 2007 年能登半島地震におい て被災した能登有料道路における常時微動計測結果

（H/V スペクトル）に基づいてゾーニングを実施す る質問を設けた。アンケートの設問内容は以下に示 すとおりである。ここに，以下の文面や図は，図番 号などを除いて，回答者に送付したものと同じであ る.

『質問 V : 2007 年能登半島地震で被災した能登有 料道路（徳田大津 I.C.〜穴水 I.C.）間において常時 微動計測を実施した結果 $(\mathrm{H} / \mathrm{V}$ スペクトル：0.05Hz の Parzen Window)を示します. 計測場所は盛土の法 尻位置で, 計測点数は 17 地点です. 得られた地盤 震動特性（H/V スペクトルの特性）に基づいて, 徳 田大津 I.C.〜穴水 I.C.間をそれぞれ複数のエリアに 分割（ゾーニング）したいと思います。あなたが提 案するゾーニングエリアの端部の位置情報を明示し てください（最大 8 分割としてください）。（図-13, 図-14，図-15参照)』

なお，この設問では，具体的な地名が与えられて いるため, 必要に応じて, 地質図等を入手して分析 することも可能である. このため, これは単なるア ンケートではなく業務ではないか, というコメント も頂いた. 深くお詫びしたい.

\section{(2) 回答結果}

図-16に 83 人の有効回答者が選定したゾーニング パターンの回答結果を示す. 同図(a)は分割数の分 布, 同図(b)は分割点の位置, 同図(c)は特異点の位 置である.

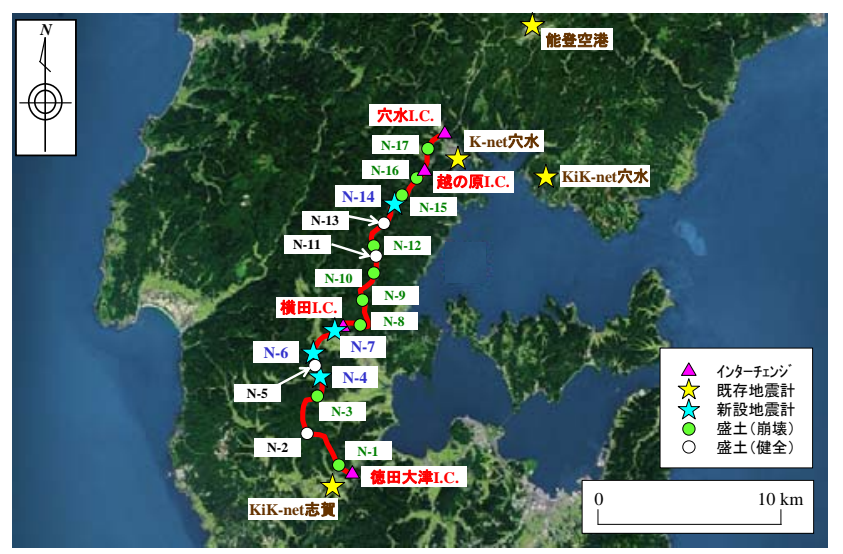

図-13 能登有料道路盛土法尻における常時微動計測位置

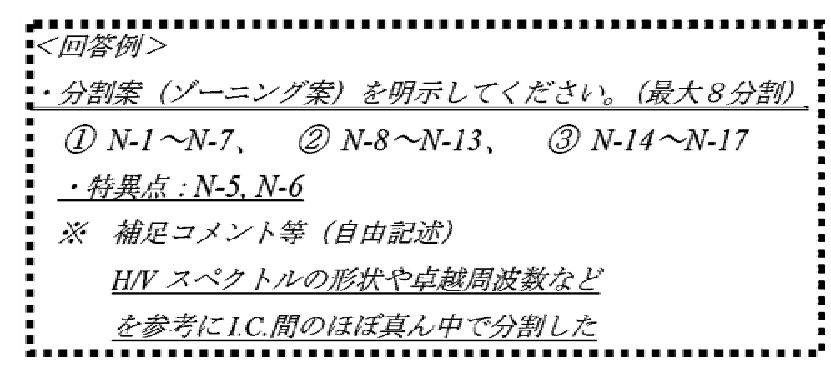

図-14 質問 V の回答例

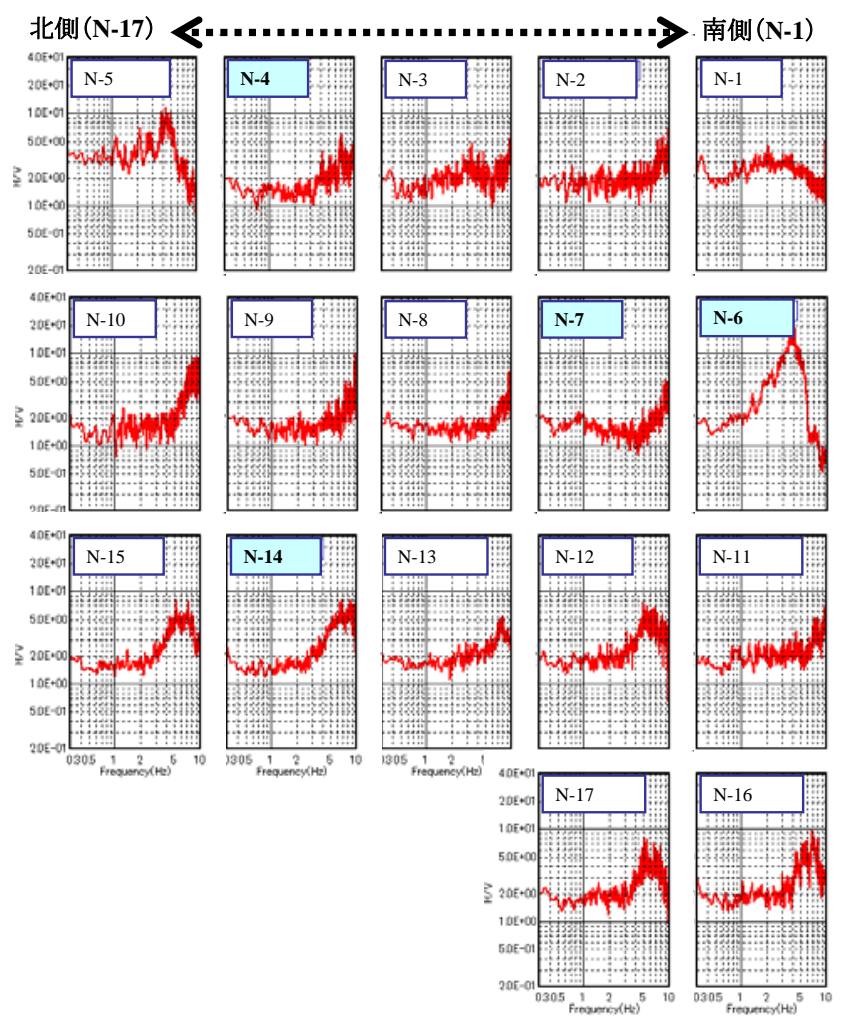

図-15＼cjkstart各計測地点における $\mathrm{H} / \mathrm{V}$ スペクトル

ここに，これらの図の横軸の回答率とは，分割数， 分割点, 特異点の回答数を有効回答者数 (83人) で除 したものである。図-16(a)より分割数としては，4 分割および5分割が全体の約7割を占めており, 図一 16(b)より分割点としては, N-4とN-5の境界および N-6とN-7の境界に対する回答率がいずれも8割を上 回っている。また, 図-16(c)より特異点としては, $\mathrm{N}-1$ の回答率が最も高くなっている.

図-17 に分割数 4 ならびに分割数 5 の場合の典型 的なゾーニングパターンを示す.ゾーニングの根拠 として数多くの回答が寄せられたのは, 各ゾーンに 対して地震計設置位置 (N-4, N-6, N-7, N-14 および KiK-net 志賀) が最低でも 1 つ以上含まれるように分 割する方法である。つまり, 常時微動計測結果から 推定される地盤震動特性よりも比較的精度が高いと 考えられる地震観測記録から推定される地盤震動特 性を利用して, 各ゾーン内の地盤震動特性を代表さ せる方法である. さらに，分割数 4 と分割数 5 のゾ ーニングパターンの違いは, N-1 の取り扱いの違い によるものである。すなわち, N-1 を H/V スペクト ルの特性や地形情報などから特異点と考えゾーニン グする方法(分割数 4) と, KiK-net 志賀と N-1 の距 離が比較的近いために両地点の地盤震動特性が類似 していると予想してゾーニングする方法 (分割数 5) の違いである.

図-18 に常時微動計測ならびにゾーニングの経験 者 38 人が選定したゾーニングパターンの回答結果 を示す. 図-18 と図-16 を比較すると, 顕著な差異 は確認できないが，経験者のほうが分割数 5 の回答 


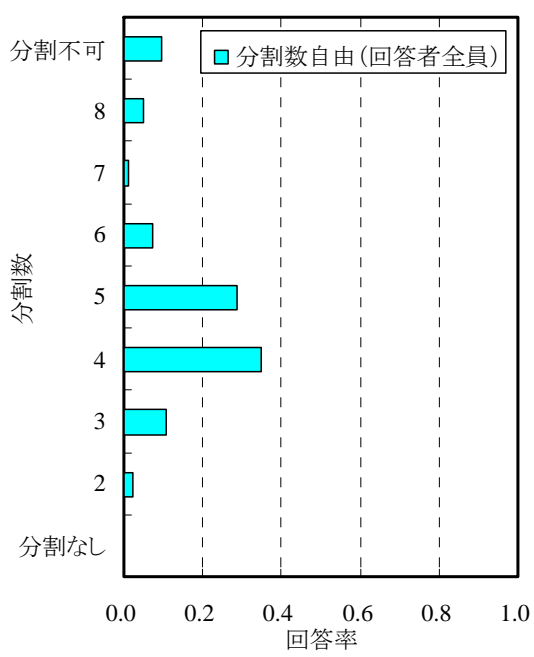

(a) 分割数の分布

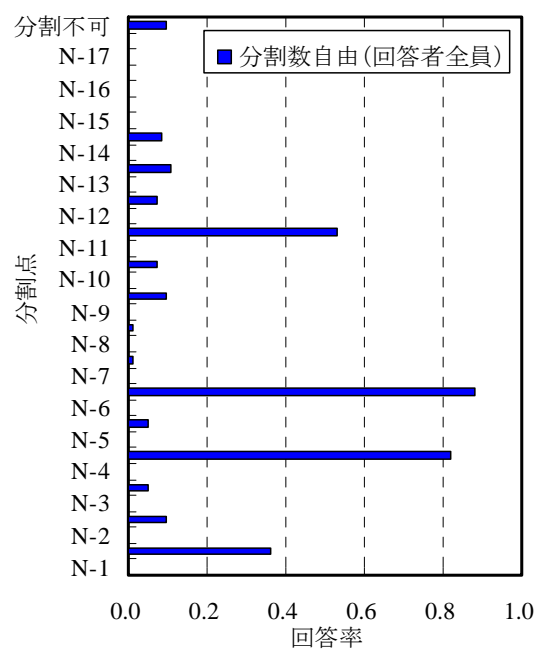

(b) 分割点の位置

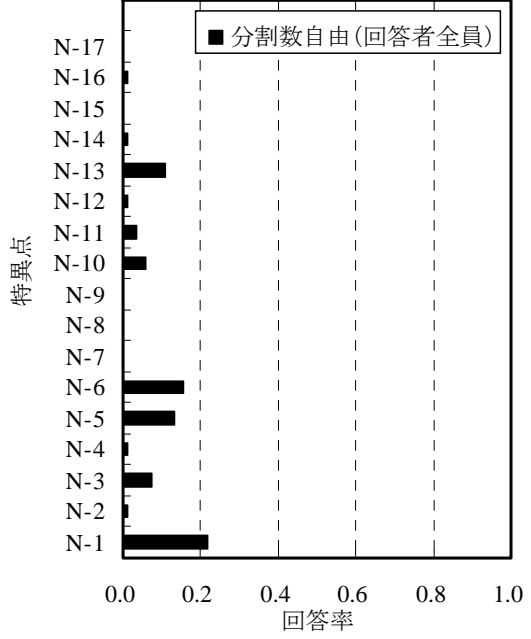

(c) 特異点の位置

図-16 分割数自由の場合のゾーニングパターン（回答者全員）

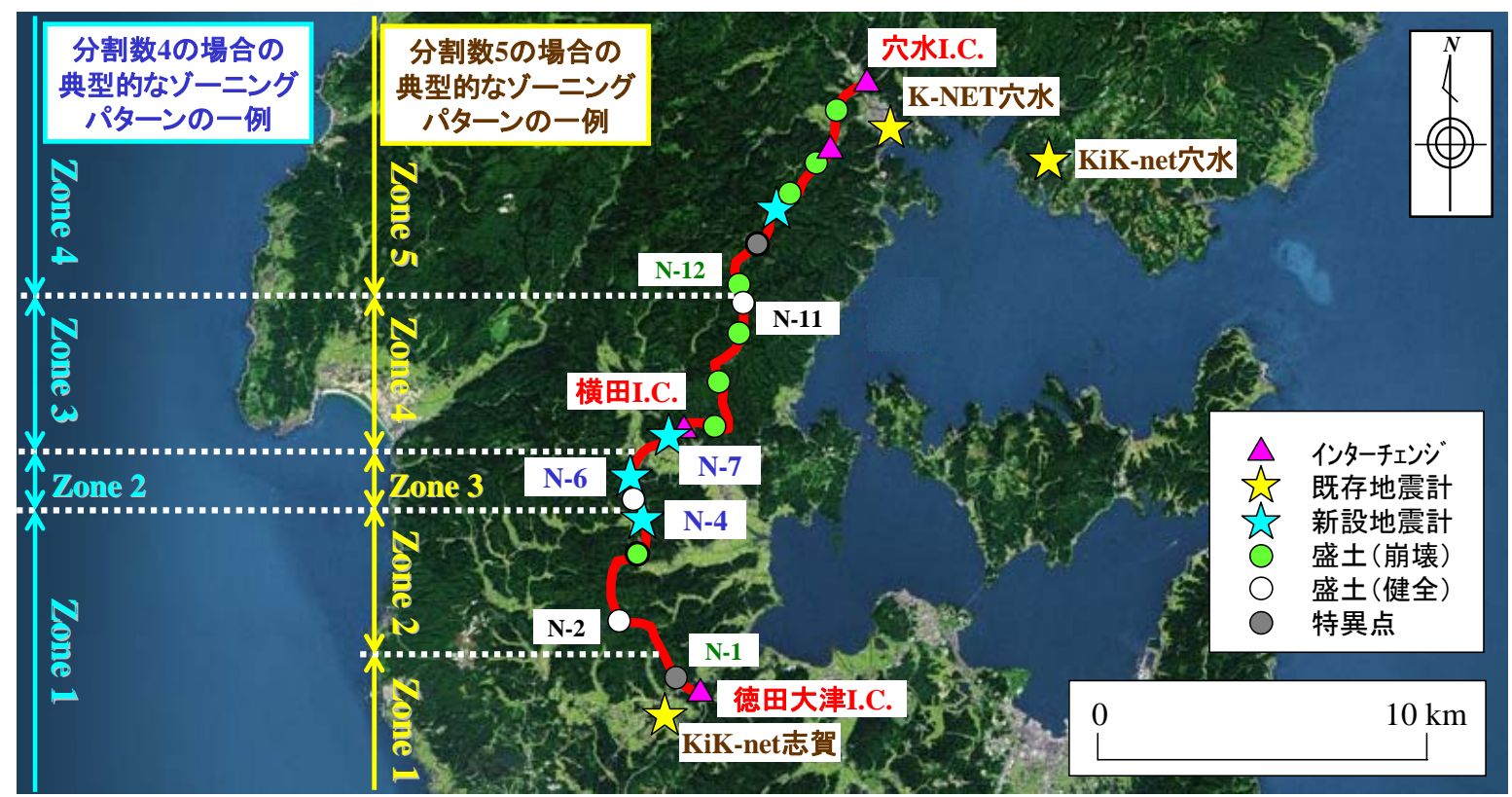

図-17 能登有料道路におけるゾーニングパターン

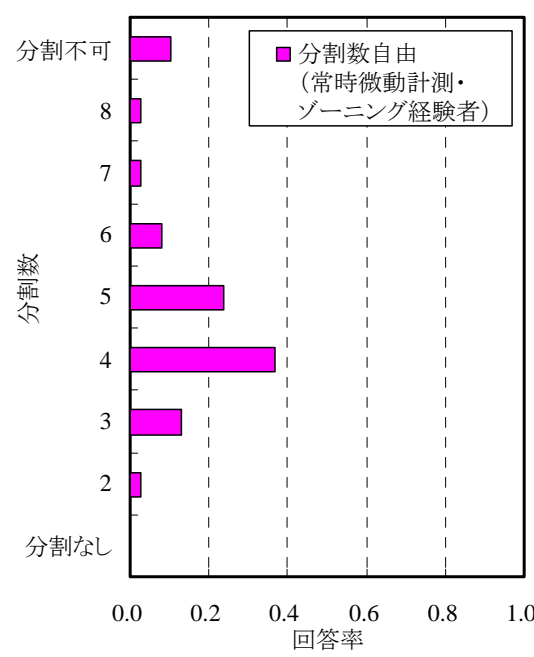

(a) 分割数の分布

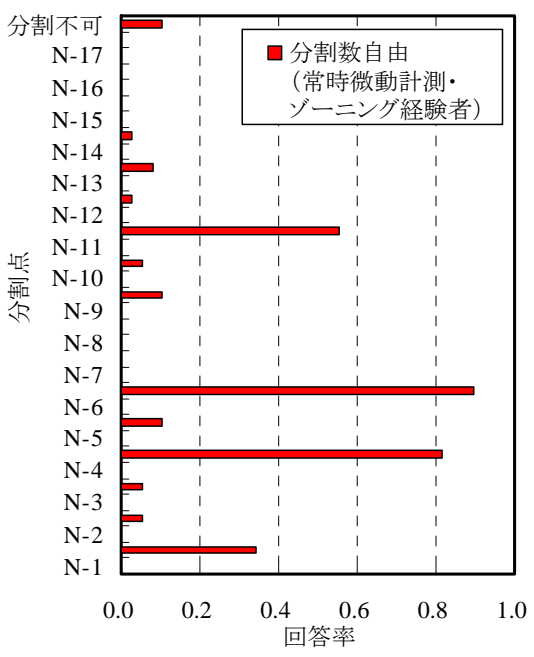

(b) 分割点の位置

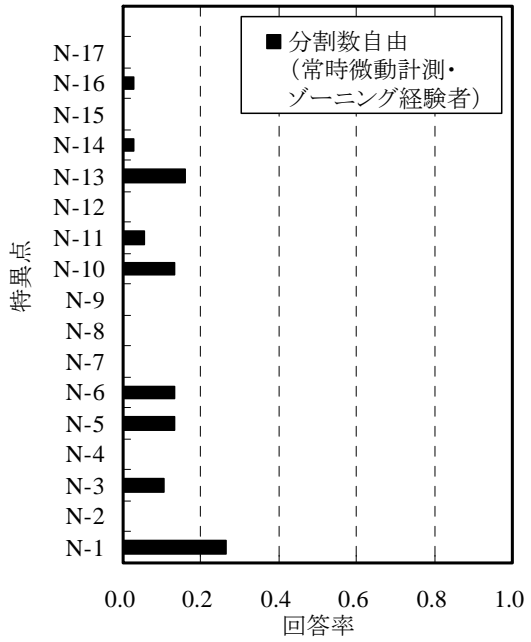

(c) 特異点の位置

図-18 分割数自由の場合のゾーニングパターン（常時微動計測ならびにゾーニングの経験者） 
率が若干低く(図-18(a)参照), さらに特異点として の N-1 の回答率が高くなっている (図-18(c)参照). この理由として, N-1 と KiK-net 志賀の地盤震動特 性が類似しているとは本アンケートの情報だけでは 十分に判断できないため, N-1 を特異点と考え，4 分割するゾーニング方法を選択したとのコメントが 比較的多く寄せられた。

これらの結果をまとめると, 分割数が自由な場合 では，端部 (I.C.地点) の取り扱い方法に差異はある ものの，50〜80\%の回答者の同意が得られる分割点 が存在した.よって, 分割数を指定しなくても, 道 路盛土におけるゾーニングには，技術者の判断の違 いがあまり大きく影響していない可能性が高いと考 えられる。

\section{7. 調査結果のまとめ}

以上のアンケート結果は, 地震動の設定手法の特 徵, 常時微動の計測方法, H/Vスペクトルによるゾ ーニングの3項目について, 以下のようにまとめら れる。

\section{（1）地震動の設定手法の特徵}

地震動の設定手法には種々のものがあり, 費用の 安いものから高いもの（作業性が手軽なものから煩 雑なもの）（入力データの少ないものから多いも の）まで, 特徵が異なる. また, 費用や作業性ほど 明瞭ではないが，信頼性や理論性・科学性も，手法 により異なる。しかし，これらの特徵は，長所にも なれば短所にもなり得るものであり, 状況に応じて

（採用する耐震診断手法にも応じて），ふさわしい 手法を採用寸ることが肝要であると思われる。本ア ンケートの結果は, 個々の技術者にとっては自明の ことであるかもしれないが，これらの各手法の特徵 を示しているものであり, 手法選択時の参考資料と して使っていただきたい. なお，本アンケートでは, アンケート文案には明示していないものの, 動的解 析を実施することを前提とした調査になっていたも のと思われる。この点については, 結果の解釈時に 留意が必要である。

\section{（2）常時微動の計測方法}

アンケート結果によれば，常時微動の計測位置を 除く常時微動の計測条件（計測時間・計測方向・使 用機器）については，回答者に概ね共通の認識があ ることが確認できた。これは，上述したとおり本ア ンケートの回答者は, 地震工学に比較的精通してい る研究者・技術者であったためである可能性が高い. しかし，未だ基準化等がなされていない常時微動計 測について，ほぼ共通した認識があることは，実務 での利用においても安心できる情報である.

一方で，常時微動の計測位置については，回答が
概ね一様にばらつく結果となった。これは, 道路盛 土の耐震診断に用いる入力地震動を検討するための 常時微動の計測条件が質問の趣旨であったが(質問 III参照), 盛土自体の特性の把握が目的であると誤 解され, 質問の趣旨がうまく伝わっていなかった可 能性がある。

また，実際の道路盛土(特に法肩)における常時微 動計測では，車両通行に伴う杂作振動の影響を受ける ことが十分に予想され，本アンケートにおいても回 答者から車両通行振動を懸念するコメントが多数寄 せられた。また，雑振動を軽減する方法として，夜 間計測を推奨する回答も多く寄せられた。しかしな がら高速道路盛土などでは, 夜間は大型車の通行が 多く雑振動を避けるのは困難という計測実績を踏ま えた回答もあった。これらを考慮すると，単なる計 測方法ではなく, 実際の計測データのデータ処理方 法に関する議論も必要であると考えられる.

\section{(3) H/Vスペクトルによるゾーニング}

上述した常時微動計測結果 (H/Vスペクトル)を与 条件の中心としたアンケート結果では, ゾーニング のパターン(高速道路盛土の分割位置や分割数など) には，基本的に回答者による大きな差異が生じない ことを確認した。これは，H/Vスペクトルによるゾ ーニングを実際に実務に適用寸る際には安心材料で ある。

また，実務上の観点として，常時微動計測結果 (H/Vスペクトルの形状やピーク周波数)だけではな く, 川や谷などの地形情報, トンネルなどの施設情 報, 維持管理の容易さ, 強震観測点の分布状況など もゾーニングの根拠として重視されることを確認で きた.

なお，一般にゾーニングは，その目的や観点 (耐 震設計・補強の観点, 維持管理の観点, 災害復旧の 観点など)によって大きく異なってくる可能性が高 い. 仮に，本アンケートの目的であった道路盛土の 耐震性評価のための地震動設定に関するゾーニング であれば，ゾーニングの目的を検討対象地点におけ るサイト特性 (地盤震動特性) がほぼ同じであるエリ アを区分することとなるが，実際には種々の目的を 同時に考慮して区分されることも考えられる．この ような複合的な目的・観点からの検討の必要性も, 今後の課題として示唆された.

\section{8. 結論}

本稿では，道路盛土の耐震性評価のための地震動 設定手法に関寸る実態と課題について把握するため に，委員会活動の一環として日本国内における地震 工学の研究者・技術者に対してアンケート調査を行 つた結果について報告した。

その結果，地震動設定手法の特徵 (長所および短 所）については，回答者に概ね共通の認識があるこ 
とを確認した。さらに，常時微動の計測条件につい ても，回答者に概ね共通の認識があることを確認し た。しかし，常時微動の計測場所については，計測 結果の利用の目的により，違いがあることを確認し た.H/Vスペクトルに基づくゾーニングについては, H/Vスペクトルがゾーニングに利用できるかどうか も含めて考え方に違いはあるものの, 半数以上の技 術者が同意できるゾーニングの分割方法が存在する ことを確認した。

今後は，このアンケート結果を踏まえ，個々の状 況下における最も合理的な地震動設定手法の合理的 な決定法などを検討していくことが望ましい.

謝辞：本アンケートの実施にあたつては，若名回答 者の皆様にご協力いただきました。性能を考慮した 道路盛土の耐震設計・耐震補強に関する研究小委員 会の委員の皆様には, アンケート結果を取り纏める 上で貴重なご意見をいただきました．能登有料道路 における常時微動計測では，金沢大学の学生（現卒 業生）の皆様（唐沢格氏，北川輝氏，北爪慎氏，山 道康平氏）および広島大学の学生（現卒業生）の皆 様（栗原園実氏，柴尾享氏，田森賢太郎氏）にご協 力いただきました。記して謝意を表します.

\section{参考文献}

1) 柴尾享, 一井康二, 秦吉弥, 田森賢太郎, 栗原園実, 湯浅香織：2009 年駿河湾の地震における東名高速道路 崩落地点の地盤震動特性評価の試み, 広島大学大学院 工学研究科研究報告, Vol.58, No.1, 2009.

2) 秦吉弥, 一井康二, 加納誠二, 土田孝, 柴尾享, 今村
孝志 : 常時微動計測に基づく高速道路盛土の入力地震 動設定法の検討，土木学会論文集 F, Vol.65, No.4, pp.529-541, 2009.

3) 秦吉弥, 一井康二, 村田晶, 野津厚, 宮島昌克 : 経験 的サイト増幅・位相特性を考慮した線状構造物におけ る地震動の推定とその応用 -2007 年能登半島地震での 道路被災を例に一, 土木学会論文集A, Vol.66, No.4, pp.799-815, 2010.

4) 一井康二, 秦吉弥 : 而震性検討のための地盤調査と調 查結果の解釈についての課題, 土木学会論文集 C, Vol.65, No.2, pp.456-466, 2009.

5) 森伸一郎, 佐伯嘉隆, 神野邦彦 : 道路盛土の簡易的増 幅スペクトルの開発, 第44回地盤工学研究発表会平成 21 年度発表講演集(CD-ROM), No.685, pp.1369-1370, 2009.

6) 秦吉弥, 一井康二, 加納誠二, 土田孝, 今村孝志 : 盛 土の耐震診断に基づく高速道路の通行機能の耐震性評 価，土木学会論文集F，Vol.65, No.1, pp.50-58, 2009.

（2011. 12. 8 受付、2012. 2. 25 修正、2012. 3. 6 受理）

\title{
A QUESTIONARY SURVEY ON THE CHOICE OF EARTHQUAKE MOTION DETERMINATION METHOD FOR ROAD EMBANKMENTS
}

\author{
Koji ICHII, Yoshiya HATA and Akira MURATA
}

The method to determine the input strong ground motion is a key factor in the seismic performance assessment of road embankments. However, the procedure to choose the method is dependent on the experience and capability of the engineers. In this study, a questionnaire survey to 83 researchers and engineers of the earthquake engineering field in Japan is conducted to reveal their recognition on the features for various earthquake motion determination method. The procedure to conduct microtremor measurement for input strong motion determination and zoning judgement based on $\mathrm{H} / \mathrm{V}$ spectrum obtained by microtremor measurements are also investigated. The results of the questionnaire are useful for a reference in practical earthquake motion determination for road embankments. 